\title{
DEVELOPMENT OF ECONOMIC THEORY - FROM THEORIES OF ECONOMIC GROWTH AND ECONOMIC DEVELOPMENT TO THE PARADIGM OF SUSTAINABLE DEVELOPMENT
}

Preliminary communication

UDK: 330.34/35-022.316

JEL classification: B10, B15, Q01

DOI: 10.17818/DIEM/2022/1.10

Accepted for publishing: July 8, 2021

\begin{abstract}
Rapid economic growth is a relatively recent phenomenon, which has been examined since the end of the 18th century. In the scientific literature researchers use the concept of "economic growth" and "economic development" when analyzing economic processes. "Economic growth", as defined by Paul M. Romer occurs whenever people use resources and rearrange them in more valuable ways. Thus, economic growth means an increase in a real national income / national output. In contrast, economic development is an improvement of the quality of life and living standards, e.g. improvement of literacy, life expectancy, and approach to environmental issues. Economic development encircles a wider range of metrics than just gross Domestic Product (GDP) per capita, it is about actual standard of living, level of environmental standards, availability and quality of housing and other aspects. The article analyzes, compares and evaluates theories of economic growth and economic development in the context of sustainable development.
\end{abstract}

Keywords: economic development, economic growth, sustainability

\section{INTRODUCTION}

People's needs have changed over the centuries, from the basic need for food and shelter to the need for self-affirmation and recognition. With the rapid development of industry in the 17th and 19th centuries, there was also the opportunity to provide ever-increasing levels of comfort to solvent consumers. There was a demand to provide such living conditions that would be possible regardless of the environment - the so-called external factors or risks. These external conditions have long been seen as a major obstacle to the physical existence and development of a society that can be considered safe and lasting. However, in the first half of the 20th century, it became clear that the main problem was the consequences of man's own actions, i.e. risks - wars, uneven 
economic development at the expense of other countries and nations, limited natural resources, ecological problems. This change in public perception should be seen as the moment when it began to develop the concept of sustainable development. Sustainability, as a generally accepted and recognizable concept, has existed since 1955, when the Russell-Einstein Manifesto (Butcher, 2005) spoke of an attitude that could ensure political responsibility for future generations or guarantee future generations a chance to exist at all. The idea of sustainability came to the public's attention following the 1972 report "Limits to Growth" published by the international think tank Club of Rome. Possible world development variants were modeled with a computer. The conclusions were not encouraging: modern civilization has growth limits set by nature itself, and people, if they want to survive, have to think about the boundary beyond which unforeseen consequences begin (Meadows, D.M., Meadows, D.L., Randers, J., Behrens, W.W., 1972). The German born - british economist Ernst Friedrich Schumacher published his book "Small is Beautiful" (1973), arguing that today's growth-based economy on a limited planet is unsustainable. E.F. Schumacher justified the need to develop sustainable, resource-saving, pollution-reducing and economically proportionate technologies (Schumacher, 1973). The concept of sustainable development was first voiced in Stockholm in 1972. At the initiative of the Swedish government, the United Nations Conference on the Human Environment was convened in Stockholm in 1972, the first such debate on environmental and development issues, marking a turning point in the attitude of world leaders towards environmental issues and foundations for a modern understanding of sustainability issues. The Conference adopted the first joint declaration in the history of the world, outlining the basic principles of development in the context of the environment, and the United Nations Environment Program (Nations, Report of the United Nations conference on the human environment, 1972). The concept of "sustainable development" was first published in Gru Harlem Bruntland's 1987 report "Our common future, also known as the Bruntland Commission's report. Definition of sustainable development"is as follows: "development that meets the needs of the present without compromising the ability of future generations to meet their own needs" (United Nations, 1987). This report analyzes the relationship between environment and development, because environment is where we all live, but development is which we are all trying to do to improve our homes (United Nations, 1987).

Today, the concept of sustainability is understood as the Venn diagram, which reflects the interplay between the three " $\mathrm{E}$ " - (Environment, Economy, and Equity (as justice or social equality)). To be sustainable, society must be able to strike a balance between the environment, the economy and social equality. Sometimes this chart shows a fourth "E"- Education, which is a very important aspect of a sustainable society. The article analyze the evaluation of the theory of economic growth and economic development, which is the basis for sustainable development, in order to find out answers to the question what are these theories that contributed to the framework of sustainable development.

Before the end of $18^{\text {th }}$ century rulers and nobles could afford various extravagances, and although the economy grew above the subsistence level, the standard of living of the average person had not changed much for centuries (Greenlaw, S.A., Shapiro, D., 2011). In the scientific literature, researchers use the terms "economic growth" and "economic development" when analyzing economic processes. The definition of "economic growth" according to Paul M. Romer's occurs whenever people use resources and rearrange them in more valuable ways (Romer, 2021). Thus, economic growth means an increase in real national income / national output. The definition of "economic development" in the Economic Dictionary (Rutherford, 2002) is formulated as follows, according to two approaches:

- the transition of the economy from agricultural production using simple technology to industrial production and a wide range of services using modern technology;

- cumulative per capita income growth accompanied by structural and institutional changes.

Therefore economic development means improving the quality of life and living standards, e.g. improvement of literacy, life expectancy, environmental issues. Development covers a wider 
range of metrics than just Gross Domestic Product (GDP) per capita, it is about actual standard of living, levels of environmental standards, the availability and quality of housing, and other aspects. The aim of the article is to analyze and compare the evaluation of economic growth and economic development theory in the context of sustainable development.

\section{HISTORY OF ECONOMIC GROWTH}

Economic growth is described as a process in which a nation's wealth increases over time. In the context of economic theory, this usually refers to an increase in wealth over time. Growth can be best described as a transformation process. (Cornwall, 2018). Whether the economy is already modern and industrialized or at an earlier stage of development, the growth process is found to be uneven and unbalanced. The term "economic growth refers to an economy in which per capita income is already rising.

\subsection{The Growth Theory of Classical Liberalism}

The growth theory of classical or economic liberalism (18th and 19th centuries) is an ideological school of political economy and a method of analysis of socio-economic processes that studies the role of the market in international economic and national economic policy (Nacional enciklopedia, 2021).

The founders of the classical economic theory are considered to be the English classical economists Adam Smith, Thomas Malthus and David Ricardo (Harris, 2007). The foundations of the theory of classical economic liberalism (and the ideology of economic policy) are related to three important trends in political and economic processes of Western Europe and the world in the 18th and 19th centuries. First, there were the internal contradictions of the mercantile system and the loss of competitiveness of products through the excessive accumulation of capital, as described by the English philosopher David Hume. Another important trend was the beginning of the Western industrialization process. The third was the emerging of the ideas of the Enlightenment, addressing also the concept of slavery, feudalism, and the promotion of the idea of equality for all men (Nacional enciklopedia, 2021).

While formulating their theories, classical economists sought to provide an overview of the broad forces that influence economic growth and the mechanisms of the growth process. Savings and productive investments in the form of profits were considered to be the main drivers of economy. Thus, the change in the profit rate was a crucial starting point in analyzing the long-term development of the economy. Classical school theories that dominated economic thinking in Britain until about year 1870 were focused on economic growth and economic freedom, emphasizing laissez-faire ideas and free competition (Encyclopaedia Britannica, 2021). Adam Smith (1723-1790) was a Scottish economist, one of the best-known founders of classical economics, also known as the "Father of Economics" or the "Father of Capitalism" (Berry, 2018). Smith opposed mercantilism and was an important defender of free market policy. Smith wrote two books on classical economics - "The Theory of Moral Sentiments", published in 1759, and "An Inquiry into the Nature and Causes of the Wealth of Nations", which came out in 1776. In this book, Smith described the idea of an "invisible hand" - the tendency of free markets to regulate themselves through competition, supply and demand, and self-interest (Weinstein, 2021). Smith also believed that the state shall not to interfere in economic development processes and that the role of government intervention and taxes in free markets should be reduced. He advocates a system, as he calls it, "natural liberty, in which the market is largely self-governing, free from excessive state interference (Harris, 2007). "An Inquiry into the Nature and Causes of the Wealth of Nations" created the concept of GDP and transformed the importing and exporting business. This concept was the basis for the development of GDP metrics to measure a country's prosperity. 
Thomas Robert Malthuss (1766-1834), British demographer, explained the relationship between income levels and population dynamics, one of the oldest problems in economic demography. In his work "Essay on the Principles of Population and How They Affect the Further Growth of Society" (1798), Malthus stated that as the human population grows, the available economic resources (i.e. food) and supply will not be able to meet demand and an economic crisis will occur (Malthus, 1798). Malthus also points out that the state should be more involved in bridging the gap between the rich and the poor.

John Stuart Mill (1806-1873), was an English political economist, one of the most influential thinkers in the history of classical liberalism. In 1848, Mills wrote the book "Principles of Political Economy", which was recognized as one of the most important economic books in the middle of the 19th century. In this book, Mills analyzes the economic role of the state and condemns protectionist policies, as well as laws banning or restricting trade union activity. (Mills, 1848). Mills contributed greatly to the theory of economic development. He analyzed various factors of economic growth and considered economic development to be a function of land, labor, and capital. Those ideas reached the highest level of development in Ricardo's work.

David Ricardo (1772 - 1823), British political economist, one of the best-known founders of classical economic theory and a follower of Smith's idea. Ricardo's most famous work is "Principles of Political Economy and Taxation" (1817). Ricardo concludes that as the population is growing, so do land rents. Ricardo also puts forward the idea of comparative advantage, a theory that free trade between two or more countries can be mutually beneficial, even if one country has an absolute advantage over other countries in all areas of production (Ricardo, 1817). Ricardo, however, fully acknowledged that in short periods of time, price depended and supply and demand. This concept became central to the classical economy, as did Ricardo's distribution theory, which divided national product into three social classes: wages for workers, profits for capital owners, and rents for landlords (Nolen, 2021).

Although the classical growth theorists do not agree on the processes, they have laid important foundations for the concepts of land, labor and capital, as well as increasing/constant/declining resource returns or border points, as well as the stationary or steady state of the economy - the situation the economy will find itself in if it can no longer grow (in various interpretations) and effective demand (Malthus, 1798). The basic idea of the classical economy was that economic processes are formed by the "invisible hand" and there is no need to intervene in the economy. Economists of classical growth theory believed that a short-term increase in real GDP per capita would lead to overpopulation, that in turn will reduce real GDP. According to classical growth theory economic growth will decline or stop due to a population growth and limited resources. Economists of classical growth theory believed that short-term growth in real GDP per capita would inevitably lead to a population growth, that in turn will limit public resources, thus reducing real GDP. As a result, the country's economic growth will slow down. Those ideas were popular until the 1930s.

\subsection{Keynesian economic growth theory}

Keynesianism is a part of the economy and an ideology of economic policy in public administration. The pioneer of Keynesianism was the British economist John Maynard Keynes (1883-1946). In 1936, Keynes's book "The General Theory of Employment, Interest and Money" was published, advocating the prevention of an economic downturn based on a government-backed policy of full employment (Brittanica Encyclopaedia, 2021). Keynes's book was the basis of Keynes's theories of economic growth: a free market economy without state intervention leads to economic bubbles and crises. To ensure better management of crises, it is essential to invest in the economy to stimulate demand and thus boost production and growth (Keynes, 2017 (1936)). Keynes acknowledged that the Great Depression was contrary to Se's law that "supply creates its own 
demand" (Say, 1834). Although there was production capacity, the markets could not sell their products. As a result, real GDP was lower than potential GDP (Greenlaw, S.A., Shapiro, D., 2011).

The growth theories of Keynesianism and neo-Keynesianism have a remarkable list of representatives, including John Maynard Keynes (1883-1946), Roy Harrod (1900-1978), Evsey Domar (1914-1997), Joan Robinson (1903-1983), Nicholas Caldor (1908- 1986), Luigi Pasineti (1930 present), James Mead (1907-1995). Among the most important authors of the Keynesian School of Economics are the British economist John Hicks the British economist with his consumptiondemand theory, who added greatly to the theory of general economic equilibrium and value theory, the New Zealand economist Alban William Housego "AW" "Bill Phillips with his work on the correlation of unemployment rates with wage growth (Phillips curve). It is worth to mention British economist Joan Violet Robinson and her ideas on the impact of monopsony or monopolistic consumer on market structure and supply, the Hungarian economist Káldor Miklós and his business cycle model, and the American economist Hyman Philip Minsky and his work on the financial crisis interpretation. The Keynesian ideological school of economics emphasizes government's role in ensuring full employment, business cycle research, and curbing inflation. The general theory of Keynesianism was also popular because it offered policy recipes to deal with the depression, recession and unemployment, especially in the 1930s, when there was a great need to combat the effects of the Great Depression, boost the post-war economic recovery and economic policy, until the neoclassical approach emerged in 1970s and 1980s. The Keynesian economy focuses on active government policies to manage aggregate demand to help avert an economic downturn (Greenwald, B., Stiglitz, J.E., 1987). A key factor in the Keynesian model is real demand, namely that expanding real aggregate demand should boost economic growth.

\subsection{Neoclassical Growth Theory}

The theory of neoclassical growth is an economic theory that characterizes how a stable rate of economic growth results from a combination of three driving forces - labor, capital, and technology (Dimand, R.W., Spencer, B.J., 2008). In neoclassical growth theory, the traditional (direct) theoretical channel through which financial globalization influences economic growth is capital increase. Growth theory suggests that financial globalization should lead to capital flows from capital-rich economies to poor economies. Theoretically, these financial flows should complement the limited domestic savings in capital-poor countries and allow increased investment by reducing the cost of capital (Kose, M.A., Prasad, E., Rogoff, K., Wei, S.J., 2010). Neoclassicists were the first to unequivocally recognize and analyze the category of technological change as a driver of economic growth, and after several empirical studies concluded that it is undoubtedly one of the most important drivers of economic dynamics (Sredojević, D., Cvetanović, S., Bošković, G., 2016).

Robert Merton Solow (1924), an American economist whose work on the theory of economic growth culminated in the exogenous model of growth named after him, is considered to be one of the best-known economists in neoclassical growth theory. In the 1950s, Solow developed a mathematical model that shows how various factors can contribute to the sustainable growth of a country's economy (Dimand, R.W., Spencer, B.J., 2008). Contrary to traditional economic thinking, he showed that the pace of technological progress contributes more to economic growth than to the accumulation of capital and the growth of the labor force. In February 1956, Solow published an article entitled "Contribution to the Theory of Economic Growth", which is one of the most important contributions to the theory of economic growth. Solow assumes that a condition of equilibrium is needed in the system of economic growth, which can be ensured by the equality of total demand and total supply. Solow points out that it is no longer possible to ignore and bypass real consumption and investment in economic growth (Solow, 1956). Solow's theory revealed a link between three sources of economic growth investment, labor, and technological progress. In his 1957 article "Technical Change and the Aggregate Production Function", Solov observed that about half of economic growth could not be 
explained by capital and labor growth (Solow, 1957). He attributed the remaining part - now called "Solow's remnant" - to technological innovation. Trevor Swan (1918-1989) was an Australian economist. In December 1956, Swan published "Economic Growth and Capital Accumulation", which was the leading work on macroeconomic modeling (Dimand, R.W., Spencer, B.J., 2008). Swan's work on the integration of internal and external balance is reflected in the Swan Diagram. Robert Solow (1956) and Trevor Swan (1956) developed a model of economic growth independently from each other, but Solow-Swan model became the basic principle of the neoclassical growth economy (Dimand, R.W., Spencer, B.J., 2008).

\subsection{The Monetaryism (Neoliberalism) Economic Growth Theory}

The founder of the Monetaryism theory is Milton Friedman (1912-2006), an American economist. Friedman believed that the role of the state in the economy should be reduced. He stated that economic growth depends on the implementation of a tight monetary policy. In the 1950s, with the interpretation of the function of consumption, which was later called the "naive Keynesian theory". Friedman summed up the neoclassical view of a long-term compromise on the Phillips curve, and in a speech in 1967, Friedman noted: "There is always a short-term compromise between inflation and unemployment, but no permanent compromise" (Greenlaw, S.A., Shapiro, D., 2011). The theory of monetary economic growth lead to globalization processes, and the unrestricted flow of capital, which was considered to be the main factor of economic growth, contributed to faster development of the agricultural sector. However, equal prosperity in all regions of the world has not been achieved.

\subsection{Endogenous Growth Theory}

The theory of endogenous growth states that economic growth in an economy is formed internally, i.e. through endogenous forces, rather than through external or exogenous forces (Romer P. , 1994). This means that the development of human capital will foster economic growth by creating new types of technologies. The theory contrasts with the growth theory of neoclassicism, which states that the main sources of economic growth are external factors, such as technological progress. The theory of endogenous growth was developed by Robert Emerson Lucas Jr. (1937) and Paul Romer (1955), who also put forward a mathematical technological explanation for economic growth (Lucas, 1988). In 1988, Lucas published an article "On the Mechanics of Economic Development", outlining the changes made to the Solow-Swan model. Lucas helped to break down the barrier between the economies of economic development (relating to poor countries) and economic growth (studying growth in rich countries). He argued that the same basic economic system should be applied to everyone and that it is important to understand how poor countries could grow (Lucas, 1988). Lucas points out the need to integrate the basic ideas of human capital presented by Schultz (1963) and Becker (1964), thus making them similar to the models of Arrov (1962), Uzava (1965) and Romers (1986) (Lucas, 1988). His model envisaged a new concept of human capital, skills and knowledge that would make employees more productive. The theory of endogenous growth mainly argues that the long-term perspective of economic growth depends on policy measures.

Paul Romer was born in 1955 and was an American economist. Romer's 1986 publication "Increasing Returns and Long-Run Growth", the result of his dissertation, is thought to have laid the foundations for the theory of endogenous growth. Romers emphasized the role of knowledge accumulation in the model of endogenous growth, pointing out that it is a by-product of the company's decisions to invest in physical capital (Romer P. , 1994). When one company acquires new knowledge, another company is positively affected by production opportunities. Therefore, the production of finished products increases the return depending on the accumulated knowledge. Every company creates knowledge in the learning process through work, and it 
immediately becomes available to everyone and completely free of charge (Sredojević, D., Cvetanović, S., Bošković, G., 2016). In his 1990 publication Endogenous Technological Change, Romers points out that endogenous growth is based on research and science and is driven by technological change that results from conscious decisions to invest in technology to maximize profits. Romer's main conclusions in this paper are that human capital stocks determine the rate of economic growth, and the characteristic large population is not sufficient to generate economic growth (Romer P., 1990). Romer and his colleagues developed an endogenous theory of economic growth and proved that the development of long-term economic growth at a steady state is possible if technical progress, increasing production returns and human capital development are put to use. In his 1990 publication "Endogenous Technological Changes" Romer analyzes solutions for the application of exogenous and endogenous growth theory in the real economy and argues that in order to eliminate the shortcomings in economic development, it is necessary to develop the concept of convergence (Romer P. , Endogenous Technological Change, 1990).

\section{ECONOMIC DEVELOPMENT THEORY}

Economic development theory focuses on quality improvement, risk reduction, innovation and entrepreneurship, which puts the economy on a higher growth trajectory. Economic development is associated with institutions, social capital, labor and capital mobility, and income and wealth equity (Feldman, M., Hadjimichael, T., Kemeny, T., Lanahan, L., 2016).

\subsection{Theoretical Framework of Classical Economic Development}

Jozeph Alois Schumpeter (1883 - 1950) was an Austrian economist and political scientist, founder of the the theory of economic development. Schumpeter's main findings are business cycle theory. The theory was based on the assumption that the main reason for economic development is innovation, which manifests itself as new technological, economical and other solutions that entrepreneurs use to develop their business (Schumpeter, 1954). This theory defends the idea that economic development is possible only in cycles, based on the creation and use of new knowledge or innovation. Classical economists assume that the most important factor in the price of a product is the cost of production. Neoclassical economists argue that the main price-driving factor is consumer's perception of product's value. According to the neoclassical perspective, the main economic problem is the organization and allocation of limited resources. This means that efficiency, meaning optimal use of available resources to maximize individual usefulness and thus the well-being of the state, becomes the most important evaluation criterion. The main research directions of the neoclassical economy are: microeconomics, which analyzes the behaviour of households and enterprises; macroeconomics, which examines economic indicators and market interactions; and econometrics, which serves as an analytical tool.

\subsection{Alternative Economic Growth Theory (Energy Economics, Ecological Economics, Modern Understanding of The Concept of "Steady State")}

Modern economic ideas about use of natural resources emerged as a very important component of economic development in the 1970s. More and more economists have come to the conclusion that existing economic growth rates, such as GDP, do not reflect the true well-being of the economy and society. As a result, new currents have emerged on how to measure development more accurately and accurately, not only in terms of economic indicators, but also in view of other options that would describe economic development more accurately. Two opposing views have emerged in the alternative economic growth theory. One idea was put forward by Meadov, Roegen, Dali, who believed that if the economy continues as before, resources will be depleted and humanity no longer will be able to exist. Others supported the neoclassical economy theories, 
mainly Solow and Stiglitz, who strongly rejected the idea that it is necessary to limit the use of natural resources.

\section{Ecological Economics}

One of the major milestones that addressed the issue of a sustainable economy was the Club of Rome. The Club of Rome is a global think tank dealing with a variety of international political issues. The Club of Rome was founded in April 1968. In 1972 Dennis Ly Meadows together with Donell H. Meadows, Jorgen Renders and William W. Behrens III published the book "The Limits to Growth", which attracted considerable public attention. The boundaries of growth book model the consequences of a rapidly growing world population and limited resource supplies. Authors used the World3 model to simulate the effects of Earth-human system interactions using computer programs (Meadows et.al., 1972). The book reiterates some of the concerns and predictions of the reverend Thomas Robert Maltus, expressed in his book "Essay on the Principle of Population" (1798). The ultimate goal of growth margins was not to make concrete predictions, but to explore how exponential growth interacts with limited resources. As the size of the resources is not known, only general action can be studied.

The authors of the book "The Limits to Growth" draw the following conclusions:

1. In the course of business as usual, i.e., if the historical growth trends remain unchanged, the limits of growth on earth will become apparent by 2072, leading to a "sudden and uncontrollable decline in both population and industrial capacity". This includes the following:

- Industrial output per capita peaks around 2008, followed by a sharp decline;

- The volume of food per capita will peak around 2020, followed by a sharp decline;

- Global services per capita peak around 2020, followed by a sharp decline;

- The world's population will peak in 2030, followed by a sharp decline.

2. The growth trends existing in 1972 could be changed in order to achieve sustainable ecological and economic stability;

3. The sooner the world's population begins to strive for sustainable ecological and economic stability, the greater the chances of achieving it (Meadows et.al., 1972).

The book "Limits to Growth", published by scientists from the Club of Rome, proves that chasing economic growth must be stopped in order to maintain economic activity in general, as it will inevitably diminish as a result of the depletion of resources and the environment. This book was an impetus for other scientists to address the issue of development and sustainability.

Romanian economist Nicholas Georgescu-Roegen (1906-1994), best known for his great opus "The Entropy Law and the Economic Process", published in 1971, in which he argued that all natural resources are irreversibly degraded when used in economic activities. Roegen's work was innovative and he was the founder of the paradigm of economics which in 1980s established the ecological economy as an independent academic sub-discipline of economics (Splash, 1999). Roegens was the first economist who put forward theoretical assumption that all of the Earth's mineral resources would be depleted at some point. Roegens argues that economic disadvantage is rooted in the fact that all natural resources are irreversibly degraded when used in economic activities. Roegens also stresses that the carrying capacity of the earth (the ability of the Earth to maintain human population and consumption) will have to decline for some time in the future as the Earth's limited mineral resources are extracted and exploited and will lead to the world economy extinction (Georgescu-Roegen, 1971). Solow and Stiglitz were Roegen's main opponents on the natural resource economy: they both argued that the substitutability of man-made capital with natural capital was realistic worldwide, so that any concern about the intergenerational distribution of mineral resources should be slightly reduced (Solow, 1974) or even ignored at all (according to Stiglitz) (Stiglitz, 1979). Contrary to this neoclassical position, Roegens argues that flow factors and fund factors (that is, natural resources and man-made capital) are essentially 
complementary, as both are necessary for the economy to function. Roegen's conclusion is that the distribution of depletable minerals between present and future generations is a major problem that cannot and should not be ignored. Roegens emphasizes that "increasing capital means depleting additional resources" and suggests that if capital increases to infinity, "capital production will quickly expend [resources]" (Georgescu-Roegen, 1979).

\section{Steady state economy}

An equilibrium economy is an economy of a constant physical wealth (capital) and a constant population. In fact, such economy does not grow over time (Georgescu-Roegen, 1975). At the beginning of the history of economics, in the $18^{\text {th }}$ century, the classical economist Adam Smith developed the concept of a stagnant state of the economy: Smith believed that any economy in the world would sooner or later reach a final state of stagnation (Smith, 1776 (2007)). Since the 1970s, the concept of equilibrium economics was mainly related to the work of the leading ecological economist Herman Daly (Smith R., 2010). Growing environmental problems in the world have led to a growing interest in the concept of a balanced economy. Herman Edward Daly was born in 1938 and is an American economist. Daly was one of the first economists to state that the current economic regime of civilization is deeply flawed and misleading, as it is clearly destroying Earth's ecology, illuminating an existential problem for all humanity and life on Earth. Daly argued that the current system, the neoclassical economy or "growth economy", where economic growth is presented as the greatest benefit, considers the environment and natural resources to be unlimited and a storehouse of resources for economic use and produces an unlimited amount of waste where waste can be thrown away based system waste. In 1977, Daly published a book "Steady-State Economics", which caused a sensation given Daly's radical view that "enough is best". Today his ideas are recognized as the key to sustainable development, and his book is widely recognized as the flagship book on the sustainable economy. As Daly's concept of equilibrium involves the ecological analysis of natural resources flowing through the economy, his concept differs from the original classical concept of steady state. Another difference is that Daly recommends immediate action to create a balanced economy by imposing permanent government restrictions on the use of all resources, whereas classical economists believed that the final steady state of any economy would develop on its own without government intervention (Daly, H., E.; Farley, J., 2011). Daly pointed out that growth and consumption must be reduced to save people (Smith R., 2010). A stable national economy is an economy of a stable size (especially a national economy, but possibly an urban, regional or global economy) with a stable population and stable consumption, which is stable or is not below its carrying capacity. The green economy uses a different approach than the neoclassical economy. The key principle is not efficiency, but the ability to balance resource extraction and use with the ability of the land to "bear" this burden.

\section{CONCLUSIONS}

1. The theory of economic growth is based on the belief that economic growth always guarantees the progress of mankind. On the other hand, the theory of the economic development of focuses on the actual results that the traditional economy is only seemingly trying to achieve - on the well-being of the population.

2. Economic growth can't be assessed on its own. Such assessment underestimates the ethical issues of wealth creation today and ignores its negative effects in the future. In addition, it tends to concentrate on the values rather than on more fair distribution of wealth. The concept of economic development believes that inequalities must be tackled not only today but also tomorrow. It also places particular emphasis on fairness for future generations, based on the concept of intergenerational justice.

3. Clear ecological boundaries. Economic growth theory often ignores the reality that ecosystem services and natural resources are limited. The theory of economic development 
uses these limitations as a starting point and builds around it a new, functioning system for evaluation, development, employment policy, etc.

4. More systemic indicators. Theory of economic growth uses simplified indicators, highlighting GDP and similar indicators as the main ones. Economic development theory uses a range of modern measurements to obtain correct answers to questions that are really important to the population, including the assessment of people's happiness and quality of life.

5. Economy developments affect structural and qualitative changes in the economy in line with technological and social progress. But economic growth is a process that provides opportunities to increase the production of goods and services in the country, quantitative growth of human and natural capital. So economic development affected by structural changes that contribute to economic growth. Economic development is closely linked to economic growth.

6. Today, the goal is to ensure the sustainable development of society, which includes economic, social and environmental aspects for society better life.

\section{REFERENCES}

Berry, C. J. (2018). Adam Smith Very Short Introductions Series. Oxford: Oxford University Press. Retrieved from ISBN 978-0-198-78445-6. https://doi.org/10.1093/actrade/9780198784456.001.0001

Brittanica Encyclopaedia . (2021, February 17). Retrieved from https://www.britannica.com/biography/JohnMaynard-Keynes.

Butcher, J. (2005). The moral authority of ecotourism: A critique. Current Issues in Tourism, 8(2), 114-124. https://doi.org/10.1080/13683500508668208

Cornwall, J. L. (2018, October 4). Economic growth. Retrieved from Encyclopedia Britannica. : https://www.britannica.com/topic/economic-growth

Daly, H., E.; Farley, J. (2011). Ecological Economics. Principles and Applications (2nd ed.). . Washington: Washington, D.C.: Island Press. Retrieved from ISBN 9781597266819. https://doi.org/10.1016/ j.ecolecon.2011.09.017; https://doi.org/10.1016/j.ecolecon.2011.10.006

Dimand, R.W., Spencer, B.J. (2008). Trevor Swan and the neoclassical growth model. National Bureau of Economic Research. https://doi.org/10.3386/w13950

Feldman, M., Hadjimichael, T., Kemeny, T., Lanahan, L. (2016). The logic of economic development: A definition and model for investment. Environment and Planning C Government and Policy, 34(1), 5-21. https://doi.org/10.1177/0263774X15614653

Georgescu-Roegen, N. (1971). The Entropy Law and the Economic Process . Cambridge, Massachusetts: Harvard University Press. https://doi.org/10.4159/harvard.9780674281653

Georgescu-Roegen, N. (1979). "Comments on the Papers by Daly and Stiglitz." . New York: Resources for the Future Press.

Greenlaw, S.A., Shapiro, D. (2011). Principles of Macroeconomics 2e (2nd ed.). Timothy Taylor.

Greenwald, B., Stiglitz, J.E. (1987). Keynesian, New Keynesian and New Classical Economics. Oxford Economic Paper, 39(1), 119-132. Retrieved from http://www.jstor.org/stable/2663132. https://doi.org/10.3386/w2160

Harris, D. (2007). THE CLASSICAL THEORY OF ECONOMIC GROWTH. In The New Palgrave Dictionary of Economics, 2nd edition. London: Macmillan.

Keynes, J. M. (2017 (1936)). The General Theory of Employment, Interest and Money: With the Economic Consequences of the Peace. Wordsworth Editions Limited. Retrieved from 1840227478, 9781840227475

Kose, M.A., Prasad, E., Rogoff, K., Wei, S.J. (2010). Postscript to "Financial Globalization and Economic Policies". In Handbook of Development Economics (Vol. 5, pp. 4360-4362). https://doi.org/10.1016/B978-0-444-52944-2.00022-7

Lucas, R. (1988). "On the Mechanics of Economic Development". . Journal of Monetary Economics, 22(1), 3-42. https://doi.org/10.1016/0304-3932(88)90168-7

Malthus, T. (1798). An Essay on the Principle of Population. London: Printed for J. Johnson, in St. Paul's Church-Yard. 
Meadows, D.M., Meadows, D.L., Randers, J., Behrens, W.W. (1972). The limits to growth. New York: UniverseBook. Mill, J. (1848). Principles of Political Economy.

Nacionālā enciklopēdija . (2021, February 17). Retrieved from https://enciklopedija.lv/skirklis/96811-klasisk\%C4\%81ekonomisk\%C4\%81-liber\%C4\%81lisma-idejisk\%C4\%81-skola,-politiskaj\%C4\%81-ekonomik\%C4\%81.

Nacionālā enciklopēdija. (2021, February 17). Retrieved from https://enciklopedija.Iv/skirklis/96811-klasisk\%C4\%81ekonomisk\%C4\%81-liber\%C4\%81lisma-idejisk\%C4\%81-skola,-politiskaj\%C4\%81-ekonomik\%C4\%81.

Nations, U. (1972). Report of the United Nations conference on the human environment. Stockholm.

Nolen, J. (2021, February 17). Encyclopaedia Britannica: Classical economics. Retrieved from https://www.britannica.com/topic/classical-economics .

Ricardo, D. (1817). On the Principles of Political Economy and Taxation. Georg Olms Verlag.

Romer, P. (1990). Endogenous Technological Change. The Journal of Political Economy, 98(5), S71-S102. Retrieved from http://links.jstor.org/sici?sici=0022-3808\%28199010\%2998\%3A5\%3CS71\%3AETC\%3E2.0.CO\%3B2-8. https:// doi.org/10.1086/261725

Romer, P. (1994). "The Origins of Endogenous Growth.". Journal of Economic Perspectives, 8(1), 3-22. https://doi.org/10.1257/jep.8.1.3

Romer, P. (2021, februāris 22). The Library of Economics and Liberty. Retrieved from https://www.econlib.org/library/Enc/EconomicGrowth.html.

Rutherford, D. (2002). Routledge Dictionary of Economics. . London and New York: Second edition, Routledge. https://doi.org/10.4324/9780203000540

Say, J.-B. (1834). A Treatise on Political Economy (sixth American ed.). . Philadelphia: Grigg \& Elliott.

Schumacher, E. F. (1973). Small is beautiful; economics as if people mattered. New York: Harper \& Row.

Schumpeter, J. (1954). Economic Doctrine and Method: An Historical Sketch. New York: Oxford University Press.

Smith, A. (1776 (2007)). An Inquiry into the Nature and Causes of the Wealth of Nations. Amsterdam: MetaLibri. https://doi.org/10.1093/oseo/instance.00043218

Smith, R. (2010). "Beyond growth or beyond capitalism?". Real-World Economics Review, 53, $28-42$.

Solow, R. (1956). A Contribution to the Theory of Economic Growth. The Quarterly Journal of Economics, 70(1), 65-94. https://doi.org/10.2307/1884513

Solow, R. (1957). Technical Change and the Aggregate Production Function. The Review of Economics and Statistics, 39(3), 312-320. https://doi.org/10.2307/1926047

Splash, C. (1999). "The Development of Environmental Thinking in Economics" . Environmental Values, 8(4), 413-435. https://doi.org/10.3197/096327199129341897

Sredojević, D., Cvetanović, S., Bošković, G. (2016). Technological Changes in Economic Growth Theory: Neoclassical, Endogenous, and Evolutionary-Institutional Approach. Economic Themes, 54(2), 177-194. https://doi.org/10.1515/ethemes-2016-0009

The Editors of Encyclopaedia Britannica. (2021, Februāris 15). Encyclopaedia Britannica. Classical economics. . Retrieved from https://www.britannica.com/topic/classical-economics.

United Nations. (1987). Report of the World Commission on Environment and Development: Our Common Future. United Nations

Weinstein, J. (2021, february 15). Internet Encyclopedia of Philosophy. Adam Smith (1723-1790). Retrieved from https://iep.utm.edu/smith/ . 